\title{
The Impact of Restrictions on Farm Animal Housing on Egg Prices, Consumer Welfare, and Production in California
}

\author{
Conner Mullally ${ }^{1}$ \\ Jayson L. Lusk
}

This draft: June 2017

\begin{abstract}
New animal welfare policies on the horizon in many states have prompted debates about the cost of achieving happier hens and hogs. A recent policy change in California offers a unique opportunity to measure the economic repercussions of minimum space requirements for egg-laying hens. Using forecasting methods and structural break tests as applied to 16 years of monthly data on egg production and input prices, we find that by July 2016 both egg production and the number of egglaying hens were about $35 \%$ lower than they would have been in the absence of the new regulations. Out-of-state eggs were able to compensate for falling California production until around the time of implementation of the new rules, at which point imports of eggs into California fell. For consumers, we estimate price impacts using panel structural break tests and difference-in-differences models as applied to five years of scanner data from the retail market for shell eggs in three California markets and three control markets. We find that the average price paid per dozen eggs was about 22\% higher from December 2014 through September 2016 than it would have been in the absence of the hen housing restrictions. The price impact fell over time, from an initial impact of about 33\% per dozen to about $9 \%$ over the last six months of the observed time horizon. These price increases correspond to welfare losses of at least \$117 million for the three California markets over the observed time horizon. Our results suggest that because of the policy change, California consumers can expect to experience annual welfare losses of at least $\$ 25$ million in future years from higher retail egg prices alone.
\end{abstract}

JEL Codes: D12, D24, Q18

Keywords: Animal welfare, food policy, agricultural policy, consumer welfare.

${ }^{1}$ Corresponding author, connerm@ufl.edu 
There are more egg-laying chickens in the United States than there are people. Until recently, virtually all of those hens lived in so-called battery cages that provide an amount of space per hen that is $28 \%$ smaller than a typical 8.5 by 11 -inch sheet of paper. Public and private efforts have emerged to provide laying hens more space, but the costs and consequences of these policies have been the subject of much debate and controversy.

On January 1, 2015, two new laws, motivated at least in part by the goal of improving animal welfare (henceforth referred to as the AW laws), went into place requiring that all eggs sold in California come from chickens provided enough room to turn around and fully extend their wings. In this article, we estimate the effects of the AW laws on egg production and consumers in California. Using thirteen years of monthly data on egg production in U.S. states, we use structural break tests and forecasting methods to estimate the impact of the AW laws on the number of egg-laying hens, quantity of eggs produced, and yield (eggs produced per 100 hens) in California. We find that output began to shrink about a year and a half prior to implementation of the AW laws. Twenty months after implementation of the AW laws, the number of egg-laying hens and total egg production in California had each fallen by about $35 \%$ because of the policy. We find no discernible impact on yield. Trade data suggest that imports from other states were able to compensate for the drop in California production until the date of implementation of the AW laws, at which point total quantity in the California market fell relative to what would have been observed had the pre-implementation trend persisted.

We conduct our consumer analysis using five years of scanner data from three California markets and three control markets. The results of panel structural break tests 
indicate that the AW laws first affected retail egg prices one month prior to implementation, closely tracking the structural break in total availability of eggs in California. Differencein-difference estimates show that the average price paid per dozen eggs was between $17 \%$ and $21 \%$ higher than it would have been in the absence of the AW laws over the 22 months following the initial structural break in retail prices. The price impact fell over time, dropping from $33 \%$ in the first three months after the initial break to $9 \%$ over the last 7 months of the observed time horizon.

We estimate the impact of the AW laws on consumer welfare in our three California markets using a first-order approximation to the sum of the equivalent variation across consumers. Our results indicate that over the 22 months observed in our data after the initial structural break in retail prices, total consumer welfare losses from higher retail prices in the three markets considered by this article were between $\$ 117$ and $\$ 144$ million, or between $\$ 12.15$ and $\$ 14.97$ per household. Scaling our estimated per household welfare impacts by the total number of households in California results in an estimated welfare loss of between $\$ 155$ and $\$ 190$ million over 22 months for the entire state. Monthly welfare losses in our three California markets fell from at least $\$ 7.5$ million after the initial price impact to at least $\$ 1.7$ million over the last seven months observed in our data set. Our lower-bound estimates for consumer welfare impacts allow for the possibility of reasonably sized welfare gains from perceived improvements in the treatment of egg-laying hens. Given that our consumer welfare analysis only covers the retail egg market, total welfare costs may be substantially higher. 
Although our focus is on the California AW laws, the policy issue studied here is of broader relevance. U.S. consumers eat around 250 eggs per person per year on average (USDA-ERS 2015), suggesting that housing restrictions for egg-laying hens have the potential to burden consumers with higher food costs. Five other states (Massachusetts, Michigan, Ohio, Oregon, and Washington) have already passed laws that will eventually limit the use of so-called battery cages. At the federal level, two common foes, the Humane Society for the United States (HSUS) and the United Egg Producers (UEP) jointly lobbied the US Congress (unsuccessfully) in 2012 for a federal law that would have required a minimum space per hen. The agreement fell apart when the Farm Bill passed in 2014 without the standards. All of these efforts follow European Union laws that banned battery cages in 2012.

There are also private efforts to reduce stocking density. Wal-Mart has encouraged its food suppliers to adopt cage free housing systems, McDonald's has pledged to phase out the use of eggs produced by hens living in battery cages, while Sodexo and Panera Bread recently announced plans to adopt new housing requirements for broiler chickens (Polansek and Nickel 2015, Nassauer 2015, Pacelle 2016). Momentum for more widespread adoption of animal-friendly housing standards appears to be growing in the private sector and the legislative arena alike, raising questions about the potential economic effects of such restrictions.

Our paper contributes to the nascent literature on the effects of regulations for improved farm animal welfare, nearly all of which has focused on the case of California. On the production side, some animal welfare advocates suggest that policies like the 
California AW laws are inexpensive ways to improve animal well-being (Hall 2008). On the other hand, the analysis of Sumner et al. (2011) suggests that a mandated shift to cagefree production in California would result in large increases in production costs. Opinions vary with respect to expected consumer impacts of regulations for improved farm animal housing standards as well. For the specific case of the California AW laws, ex-ante simulation estimates of Allender and Richards (2010) show that California consumers would require a one-time payment of $\$ 106$ million to be compensated for implemenation of the policy. Using data on wholesale egg prices and quantities spanning one year before and seven months after passage of the AW laws, Malone and Lusk (2016) estimate far larger welfare losses of between $\$ 408$ and $\$ 853$ million annually. In contrast, Ward (2014) estimates that a national ban on battery cages would result in a net welfare gain of $\$ 19$ billion, albeit concentrated among a small number of individuals with strong preferences for animal welfare. By analyzing data on production as well as retail prices and quantities collected before and after the implementation of the AW laws, we provide insight into these debates.

Malone and Lusk (2016) were the first to conduct an ex-post analysis of the AW laws, and we build on their analysis in several ways. We use retail scanner data rather than wholesale prices and quantities. We conduct formal tests of the date upon which the AW laws began to have an effect, and we measure impacts over a longer time horizon. We account for variation in price impacts across markets and products in our consumer welfare analysis, and estimate the impacts of the AW laws on production. As far as we know, our 
paper is the first to provide an ex-post estimate of the impact of policy restricting farm animal housing on production, retail prices, and consumer welfare.

\section{Background}

Figure 1 shows the number of egg-laying hens in California (taken from the Chicken and Eggs report of the USDA's National Agricultural Statistics Service) as well as a timeline of events leading up to implementation of the AW laws.

\section{[FIGURE 1 ABOUT HERE]}

The California egg industry suffered from a Newcastle outbreak in 2002-2003 that killed over 3 million egg-laying hens. The total number of egg layers never returned to its pre-outbreak level but stabilized shortly after the USDA quarantine of affected areas was lifted in September 2003. California voters passed Proposition 2 in 2008, banning confinement that prohibits animals from turning around freely, lying down, standing up, and fully extending their limbs. The measure applied to chicken battery cages, veal crates, and sow gestation crates. However, there is very little veal, pork, or broiler production in California. In contrast, California is the $7^{\text {th }}$ largest egg producing state in the nation (producing 4.5 billion eggs in 2014 or $5.1 \%$ of the nation's total according to USDANASS). Thus, the potential impacts of the AW laws are largest for the egg industry. Recognizing that cheaper imports from other states would soon dominate the egg market, the California state legislature passed AB 1437 in 2010, banning the sale of eggs in California produced under conditions that do not comply with Proposition 2. 
The legislation behind the AW laws (Proposition 2 and AB 1437) did not provide specific rules defining sufficient space for egg-laying hens. In July 2012, the California Department of Food and Agriculture (CDFA) proposed regulations stating that enclosures with nine or more birds must allow a minimum 116 square inches of floor space per bird, while enclosures with fewer birds must allow additional space as prescribed by a formula provided by CDFA. Relative to UEP recommendations, the CDFA standards would result in between one-third and one-half as many birds per cage using standard battery cages (Bell 2013). The proposed rules were passed in May 2013 and were ultimately implemented in January 2015. The CDFA rules are enforced through inspection of California and out-ofstate farms. Possible penalties for violations of the new regulations were published well in advance of implementation of the AW laws, including "putting the eggs off sale, seeking injunctive relief and revoking an egg handler's license" (California Department of Food and Agriculture 2013). However, an explicit schedule of penalties and enforcement plan was not passed into law until June 2016.

Reducing stocking density in order to comply with the AW laws can be accomplished without making large capital investments. Producers can remove partitions in existing cages to create more space per bird (Bell 2013). However, any departure from housing standards that were already cost minimizing will raise average costs of production. Apart from the obvious implications for average cost of devoting greater space per bird, hens with additional space may burn more calories and therefore require more feed, while labor costs per hen may increase as well. Greater contact with other birds could result in higher mortality rates and greater expenditures on pullets (young birds). Each of these 
factors led Sumner et al. (2011) to conclude that moving California egg producers to noncage production systems would raise average costs of production by between $41 \%$ and $70 \%$. Since producers do not actually have to move to a non-cage system to comply with the AW laws, the figures given by Sumner et al. (2011) may be an overestimate of the increase in costs resulting from the policy. But even as an upper bound, the projected cost impacts from Sumner et al. (2011) underscore the potential of the AW laws to have noticeable effects on production.

\section{Impacts of the AW laws on California egg production}

Although the AW laws did not go into effect until 2015, the dynamic nature of egg production suggests that egg producers would have been affected beforehand. For example, California producers may have reduced expenditures on major investments such as facilities and equipment shortly after passage of the laws, as expectations of higher future production costs could lower the stream of net benefits from these investments.

However, flock size is the major channel through which the AW laws are likely to affect California egg production over the time horizon shown in figure 1. The useful life of a typical egg-laying hen runs from about 60 to over 100 weeks, depending on whether a producer decides to induce a second or third production cycle. If a producer expects higher production costs in the future, and higher costs will not be completely offset by rising output prices, then he or she will reduce production by cutting flock size relative to levels that would be observed in the absence of the policy change. These changes would start to occur once the useful life of replacement birds begins to overlap with the months following AW law implementation. 
By mandating a shift to a different production technology, the AW laws might also affect yield. Whether we should expect the AW laws to have a positive or a negative effect on yield is unclear. On one hand, rising production costs might force low-productivity farmers out of the industry. On the other hand, the AW laws will force farmers remaining in the industry to alter their production practices in a way that might decrease output per hen (otherwise producers would have already adopted the practices enforced by the CDFA standards). Therefore, we expect any negative impacts on production to operate primarily through reductions in flock size.

It is possible that the passage of Proposition 2 would have affected egg production any time after passage. However, the adoption of CDFA standards (which may have sent a strong signal to producers about the eventual implementation of the law) coupled with the replacement cycle of egg-laying hens suggests that policy impacts most likely began in 2013. Given these conjectures, we empirically estimate the timing and magnitude of the impacts of the AW laws on California egg production below.

\section{Empirical approach for impacts on California egg production}

Estimates of policy impacts usually compare a group receiving an intervention (i.e. the "treatment group") to a control group. The control group is used to establish the counterfactual "no policy change" scenario in comparison to the treatment group. Trade data provided by CDFA through a FOIA request show that California received shipments of eggs from 34 different states from 2012 - 2016. States that produce eggs but do not ship to California are most likely connected to other states through egg trade, and trade connections between states make it difficult to select a valid control group. For example, 
suppose that the AW laws reduce egg production in California, increasing excess demand in California at prevailing market prices. While neighboring states might be strongly impacted as a result of relatively low costs of shipping eggs to California, the Midwest has relatively lower feed prices while the Southeastern states face lower labor costs, perhaps making it possible for states in those regions to expand production in order to serve the California market with relatively little impact on marginal cost.

Given the difficulties associated with identifying a control group, we use timeseries methods to estimate causal effects of the AW laws on the number of egg-laying hens, yield, and quantity of eggs produced in California. Our main identifying assumption is that any unobserved factors correlated with an outcome of interest are independent of whether the AW laws are in place, conditional on a set of observed covariates. In his paper on timeseries estimation of policy impacts, White (2006) calls this assumption "conditional independence given predictive proxies" or CIPP. CIPP can be roughly interpreted as a time-series version of the Conditional Independence Assumption invoked to identify causal effects through regression and matching methods in cross-section and panel data settings (Angrist and Pischke 2009). If CIPP holds, policy impacts can be estimated by forecasting methods (White 2006).

\section{Data and results for impacts on California egg production}

Data on our three outcomes (the number of egg-laying hens, eggs produced per 100 hens, and quantity of eggs produced) are taken from the USDA Chickens and Eggs report, beginning in January 2001 and ending in July 2016, downloaded from the National Agricultural Statistical Service (NASS) web site. Our pool of covariates includes feed 
prices collected from Feedstuffs magazine, ${ }^{2}$ the livestock/poultry worker wage for California as reported by NASS, ${ }^{3}$ as well as the retail per-gallon of price of diesel and the per-kilowatt hour price of electricity collected from the U.S. Department of Energy. Feed accounts for about two-thirds of production costs in a typical commercial egg-laying operation (Otto, Ibarburu and Schulz 2013). No cost data were available for pullets, land, or equipment and facilities. All prices were converted to August 2016 dollars using the U.S. CPI from the Bureau of Labor Statistics (BLS).

We estimate the impacts of the AW laws on production outcomes as follows. First, we apply Augmented Dickey Fuller (ADF) tests of the null hypothesis of a unit root to the natural $\log$ of each variable in our data set, both in levels and in first differences. After confirming that all variables are integrated of the same order, we apply the Engle-Granger (1987) procedure, testing the null hypothesis of a unit root in the residual from the cointegrating equation for each outcome. The results of our unit root tests define the set of appropriate forecasting techniques, and our forecasting models should be estimated using data that are free of any effects of the AW laws or any continued instability of the hen population in the wake of the Newcastle outbreak. Therefore all unit root tests are applied

\footnotetext{
${ }^{2}$ Our feed price formula replicates as closely as possible the formula used by the Iowa State University Egg Industry Center. Their formula calculates the feed price as $67 \%$ corn, $22 \%$ soy meal, $8 \%$ limestone, and $3 \%$ other ingredients. Feedstuffs provides corn and soy meal prices, but we lack prices for the other ingredients. We calculated the feed price as $(0.67 / 0.89) \times$ corn price $+(0.22 / 0.89) \times$ soy meal price. For California, we use the simple average of Los Angeles and San Francisco prices for each grain.

${ }^{3}$ We used linear extrapolation to transform the quarterly wage reported by NASS into a monthly variable.
} 
to data observed between the lifting of the Newcastle quarantine (September 2003) and the adoption of new farm animal housing regulations by the CDFA (May 2013).

Once we have selected a forecasting model that is appropriate given the results of our unit root tests, we test for unknown structural breaks in the model parameters using the method of Bai and Perron (1998). The results of the structural break tests enable us to state more precisely when the AW laws began to have an effect on California egg production, as well as the month in which the California egg-laying hen population had stabilized after the Newcastle outbreak. We conduct the structural breaks test using the number of egglaying hens as the outcome. We do so because the impacts of the Newcastle outbreak and the AW laws should be strongest for the number of hens, resulting in the greatest degree of precision in estimation of the break dates.

The results of our ADF tests and the Engle-Granger procedure indicated that all variables have unit roots in levels but not in first differences, and that none of the outcomes is cointegrated with the covariates; these results are shown in the supplementary appendix. Based on these results, we choose to forecast each outcome using an autoregressive distributed lag model in first differences:

$$
\Delta y_{t}=\alpha+\sum_{k=1}^{K} \rho_{k} \Delta y_{t-k}+\sum_{l=0}^{L} \beta_{l} \Delta x_{t-l}+\Delta \varepsilon_{t}
$$

All observed variables are in natural logarithms. In order to simplify notation equation (1) is written with a single covariate. The combination of lags of the dependent variable and each covariate is selected to minimize the Bayesian Information Criterion (BIC). If necessary, we add more lags of the dependent variable until a Breusch-Godfrey 
autocorrelation test of 12 lags of the residual returns no p-values less than 0.10 . For quantity produced and yield, we also include the first differences of 11 dummy variables for the months of the year, as both variables exhibit strong seasonal patterns.

Next, we apply the Bai and Perron (1998) test for unknown structural breaks to equation (1) using the natural log of the quantity of egg-laying hens in California as the outcome. After trimming the first and last $15 \%$ of observations (as recommended by Andrews (1993)), we search across the remaining dates for a structural break. Each iteration of the search requires that we select a break date, define a dummy variable equal to 1 for all dates after the break, add the break dummy as well as all interactions between the break dummy and our independent variables to equation (1), and estimate the resulting model. We retain the break that gives the smallest sum of squared residuals for the estimated model, and test the null hypothesis of no breaks against the alternative of one or more breaks at the $5 \%$ level using the supremum Wald statistic and critical values included in Bai and Perron (1998). We continue searching for additional breaks within each subsample split by a statistically significant break date until we fail to reject the null hypothesis of no additional breaks.

Applying the Bai and Perron procedure to the parameters of equation (1) for the number of egg-laying hens identifies two structural breaks: one occurring in January 2004 and a second break in September 2013. We therefore proceed by estimating equation (1) for each outcome using data from February 2004 through September 2013 (117 months), and then use the resulting parameter estimates along with observed data to compute dynamic forecasts for each outcome from October 2013 through the end of the observed 
time horizon in July 2016 (34 months). ${ }^{4}$ In computing the forecasts, observed values of the covariates are used in each period, while the $k$ th lag of the dependent variable in the forecast for period $t$ is replaced with its forecast if period $t-k$ occurs on or after October 2013. Under the assumption that our forecasts are unbiased, a valid estimate of the policy impact in each period is given by the forecast error, while the average policy impact across all 34 months is estimated using the average of the forecast errors.

Statistical inference on our forecasts is conducted using simulation under the assumption that the regression parameters from equation (1) are i.i.d. multivariate normal. We take 1,000 random draws of the regression parameters from a multivariate normal distribution with means and covariance parameters equal to their sample estimates. With each random draw, we calculate the entire sequence of forecasts. The standard error for the forecast in period $t$ is estimated using the standard deviation of all 1,000 period $t$ forecasts. The standard error of the estimated average policy impact is calculated as the standard deviation of the 1,000 simulated average forecast errors. 95\% confidence intervals are calculated using the $2.5^{\text {th }}$ and $97.5^{\text {th }}$ percentiles of the simulated forecasts.

\section{[TABLE 1 ABOUT HERE]}

Table 1 presents the average forecast error for each outcome after September 2013, i.e. the average monthly impact of the AW laws on each outcome. The policy impacts suggest that the AW laws had a strong negative effect on California egg production, and

\footnotetext{
${ }^{4}$ Regression output for our forecasting models is included in the supplementary appendix.
} 
that impacts operated through reductions in flock size. In the 34 months covered by our forecasts, the number of egg-laying hens in California was reduced by an average of 4.4 million birds each month relative to what would have been observed in the absence of the AW laws. This reduction in flock size corresponds to $22 \%$ of the average number of egglaying hens observed in California each month between October 2013 and the stabilization of the hen population following the Newcastle outbreak in 2003. Egg production was also strongly affected, falling by an average of $26 \%$ each month relative to its pre-break mean. At the same time, the AW laws do not appear to have affected output per egg-laying hen. All policy impacts are precisely estimated.

\section{[FIGURE 2 ABOUT HERE]}

Figure 2 shows the sequence of forecasts for the quantity of eggs produced in California each month as well as its $95 \%$ confidence interval. The estimated policy impact in each period is given by the vertical distance between the forecast and the observed value of the time series. While the average impacts given in table 1 obscure the evolution of the policy impacts, figure 2 shows that once the policy began to have an effect, the reduction in egg production was severe. The percent impact on egg production grew in absolute value from a decrease of about $7 \%$ relative to what would have been produced in the absence of the AW laws in October 2013 to a decrease of about 40\% by November 2015. Quantity produced rebounded slightly by July 2016 , with an estimated decrease of about $36 \%$ relative to the counterfactual scenario. 
In the supplementary appendix, we present graphs of the forecasted and observed series for the number of egg-laying hens and yield. The forecasts and observed series for hens move in lock step with those of egg production, while in the case of yield we are largely unable to disentangle the forecasted series from the observed data. We also present two robustness checks on our identification strategy. First, we re-estimate each forecast regression using data running from our first estimated break through October 2011. We then forecast each outcome over a 34-month period, just as in our main results, beginning in November 2011 and ending in September 2013, prior to any realized effects of the AW laws. Next, we apply our forecast model to each of the 24 other states for which we have complete data. If our identification strategy is successful in eliminating bias, the first robustness check should result in forecasts that closely track observed outcomes, since no policy effects had yet been realized. The second robustness check should fail to uncover noticeable policy impacts in a large number of states, since spillovers should be either small and diffuse or large and concentrated in a small number of states. The results of all checks strongly support our identification strategy.

Alternative explanations for the substantial estimated negative effects of the AW laws on California egg production include disease outbreaks, the California drought, and decreases in demand. Other than the $2002-2003$ Newcastle outbreak, the only major disease event included in our observed time horizon is the 2015 outbreak of avian influenza. Data downloaded from the USDA Animal and Plant Health Inspection Service (APHIS) indicate that no egg-laying hens or pullets died in California because of the avian influenza outbreak. Effects of the disease were concentrated in the Midwest. If anything, 
the avian influenza outbreak would have created an incentive for California producers to expand production, suggesting that our estimated impacts understate the effects of the AW laws on hens and egg production. As for the California drought, impacts on the egg industry are probably small because feed for the vast majority of birds is imported from other states (Howitt et al. 2015). Lastly, by combining our NASS production data with data on imports of shell eggs into California from 2012 through 2016 obtained from CDFA through a FOIA request,${ }^{5}$ we can examine whether total availability of eggs in California fell with in-state production. A fall in total availability over the observed time horizon might reflect a decrease in demand.

\section{[FIGURE 3 ABOUT HERE]}

As we can see in figure 3, total quantity of eggs in California held quite steady until implementation of the CDFA housing regulations. While we cannot observe the counterfactual trend, the data suggest that demand shifts are not driving impacts on egg production. We regressed the natural log of imports plus in-state production on an intercept and a linear trend, and then conducted a Bai and Perron (1998) structural break test as above, limiting our test to a single structural break. The resulting estimates indicate a structural break in the trend and intercept at February $2015(p<0.0005)$, after which point the total availability of shell eggs was on average about $10 \%$ lower each month relative to the months before the estimated break. Since demand for eggs tends to be highly inelastic

\footnotetext{
${ }^{5}$ CDFA stated that all records for prior years had been destroyed.
} 
(Okrent and Alston 2011), a 10\% drop in quantity has the potential to generate large increases in prices. Based on our results, we would expect any price impacts to be observed around the time of AW law implementation rather than before.

\section{Impacts of AW laws on egg prices and consumers in three California markets}

We now turn to estimating the impacts of the AW laws on consumers in three California markets. Our objective is to estimate impacts on the average price paid per dozen eggs, as well as impacts on consumer welfare. We focus exclusively on the shell egg retail market. Shell eggs make up the vast majority of eggs sold in California (Sumner et al. 2008). However, because our focus is only on a segment of the California egg market, our consumer welfare estimates will understate the total impacts of the AW laws. ${ }^{6}$

\section{Data for consumer impacts}

Our price and consumer welfare analysis relies on retail scanner data for shell eggs from Nielsen for Los Angeles, San Francisco, San Diego and their surrounding areas, as well as Chicago, Phoenix, Salt Lake City/Boise and their surrounding areas as observed from September 2011 through September 2016. ${ }^{7}$ In our analysis, products from the latter three markets serve as controls. The data set was constructed by combining weekly reports from participating retailers. Nationally, Nielsen scanner data include retailers that account for $90 \%$ of all grocery sales volume. There are 12.7 million households in the three California

\footnotetext{
${ }^{6}$ The hospitality industry, for example, also has to purchase eggs that comply with the AW laws. In addition, although liquid eggs and egg substitutes need not comply with the AW laws, we would expect their prices to rise as consumers substitute away from shell eggs.

7 A complete list of the counties and retailers included in the Nielsen market areas can be found in the supplementary appendix.
} 
markets, or about $76 \%$ of the total California population. 7.3 million households live in our three control markets.

The data set includes observations on 1,184 shell egg Universal Product Codes (UPCs), along with the value of sales in each market, the quantity sold in each market, and a rich set of product characteristics. 393 UPCs were sold in California as well as the control states, 262 were sold exclusively in California, and 429 were sold only in the control markets. In what follows, we treat each UPC sold in multiple markets as a collection of distinct products, so that a UPC observed in a control state can be treated as a product belonging to the control group regardless of whether it is also sold in California.

For each product, we create a time series of average unit values by dividing the value of sales by total dozens sold. As such, we have unit values and not prices per se - a distinction we will return to later. For the Western markets in our data, we convert prices (unit values) to August 2016 dollars using the Western Urban CPI from BLS. We use the Chicago CPI from BLS for Chicago. In order to limit the volatility in observed prices and quantities commonly encountered in high-frequency scanner data, we collapse the data set into a monthly panel, assigning each week to the month in which it ends (Ivancic, Diewert and Fox 2011). ${ }^{8}$ The final data set consists of 51,263 monthly observations of shell egg products with positive quantities sold across the six markets.

\footnotetext{
${ }^{8}$ Converting the data to a monthly frequency also makes it possible to conduct robustness checks that bring in other data sources observed at lower frequencies, as we do in the supplementary appendix.
} 


\section{Empirical approach for identifying impacts on California consumers}

For our consumer analysis, we must choose between measuring impacts through forecasting methods or by comparing California to our control markets. Forecasting methods would enable us to avoid using a control group potentially affected by spillovers, but are problematic because of the impact of the avian influenza outbreak in 2015. Our analysis of production impacts suggests that price effects in California were not likely to be felt until around January 2015, when the AW laws were implemented. The 2015 avian influenza outbreak reached critical levels in April, and in the subsequent two months, the total number of egg-laying hens in the U.S. fell by about $10 \%$ according to the NASS data set used in our production analysis. Total flock size in the U.S. did not return to preoutbreak levels until April 2016.

Once markets had time to adjust by shipping additional eggs to high-price markets, the price impacts of the avian influenza outbreak should have been similar in all states engaged in the interstate egg trade. To see why, suppose that for every pair of states, the per unit cost of shipping eggs from one state to the other (including fuel, red tape, etc.) is constant and unaffected by the disease outbreak, and that the marginal cost of producing for different states (other than California) only varies because of shipping costs. For a profit-maximizing producer operating under this scenario, the marginal revenue from selling to state A minus the marginal revenue of selling to state B will equal the cost of shipping an egg to state A minus the cost of shipping to state B in equilibrium. As long as the own-price elasticity of demand for any given product is not too different across states, 
price changes caused by the avian influenza outbreak will be similar across states, at least for products sold in multiple markets.

The fact that the price effects of avian influenza should have been similar across U.S. states has two implications for our empirical methodology. First, a forecasting approach to measuring price impacts may conflate the effects of the AW laws with those of the avian influenza outbreak. In the case of egg production, we would expect any bias in the forecasting approach to make impact estimates more conservative, as already discussed. However, since the disease outbreak as well as the AW laws could have raised egg prices, forecasting may result in estimates of price impacts that overstate the effect of the AW laws.

The second implication of similar avian influenza price effects across markets is that a difference-in-differences (DD) approach to estimating impacts of the AW laws on California retail egg prices ought to reduce bias relative to a forecasting approach. The simplest DD estimator requires that we first calculate the change in the average price per dozen eggs in California between the pre-intervention and post-intervention periods. We then calculate the same change in our control markets, and the policy impact is given by the change in California net of the change in the control markets. By taking differences across California and other markets, much of the effect of avian influenza on prices of products sold in multiple states should be removed from our estimates of price impacts caused by the AW laws. 
Two key assumptions must hold for DD to identify the policy effect of interest. The first assumption is that the trend in egg prices would have been the same in California and control markets in the absence of the AW laws. As discussed above, this is a reasonable assumption for individual products sold in California as well as in control markets. Whether a common price trend will hold when calculating average price using all observed products is less clear. We test the common trends assumption by checking whether the difference between the average price per dozen eggs in California and the average price in our pooled control markets contains a unit root (i.e. whether the two price series share a cointegrating vector of $[1,-1])$ using data observed prior to any realized price effects of the AW laws. ${ }^{9}$ After verifying via an ADF test that both price series contain a unit root in levels but not in first differences, we find that an ADF test rejects the null hypothesis of a unit root for the difference in average prices at the $5 \%$ level. ${ }^{10}$ We conclude that the two series shared a common trend prior to any realized effects of the AW laws.

The second assumption that must hold for DD to identify the price impacts of the AW laws is that there are no spillovers from California to control markets as a result of the policy change. However, the trade linkages that lend support to the common trends assumption also create spillovers. Our analysis of production impacts suggests that egg prices may have risen as early as 2013, both inside and outside of California because of linkages between states through trade, but that price increases were most likely small in

\footnotetext{
${ }^{9}$ We estimate the date at which the AW laws began to affect California retail egg prices using a panel structural break test described below.

${ }^{10}$ Results are found in the supplementary appendix.
} 
the years leading up to implementation of the AW laws. Regardless, failing to detect price increases in California prior to implementation of the AW laws will result in conservative estimates of impacts on prices and consumer welfare. Of potentially greater concern is whether a spike in the supply of eggs in non-California states caused by a reduction of imports into California reduced egg prices outside of California.

The existence of a strong trade network for eggs and the fact that producers were aware of the impending implementation of the AW laws for seven years suggests that price spillovers were most likely negligible. The U.S. egg industry not only trades across states, but is active in international trade as well, a point that can be easily verified using the USDA's Global Agricultural Trade System data base. ${ }^{11}$ In other words, there are many potential destinations for output. As producers withdraw output from California and look elsewhere to sell their eggs, profit maximization (i.e. equating the marginal net returns of eggs sold in different states) as well as the long planning horizon available to producers in advance of the California policy change suggest that the increase in supply to any single market will be very small, as will any corresponding price changes. DD appears to be the proper choice for estimating the impacts of the AW laws on prices.

Scanner data summary statistics and simple impact estimates

Table 2 presents summary statistics for price, quantity, and selected product characteristics in California and the pooled control markets. Data are split into a pre-impact period

\footnotetext{
${ }^{11}$ https://apps.fas.usda.gov/gats/default.aspx.
} 
(November 2014 and earlier) and a post-impact period. The month at which the data are split was estimated using a panel structural break test described in the next subsection.

\section{[TABLE 2 ABOUT HERE]}

Prior to any AW law impacts, prices are higher in California; this is as we would expect, since California is a net egg importer and its egg producers faced relatively high production costs even before implementation of the AW laws (Sumner et al. 2008). In addition, both California and control market sales are dominated by white, conventionallyproduced eggs. Other than results for quantity, all summary statistics were generated after weighting by units sold in a given month and market.

The rightmost column of table 2 shows simple DD estimates (computed using differences in weighted sample averages) for the AW-law impact on each variable. Weighting by quantity ensures that our price impacts are properly interpreted as impacts on the average price paid per dozen eggs each month, despite the fact that we observe unit values rather than prices. Our impacts on product characteristics estimate the effect of the AW laws on the proportion of eggs sold each month with a given characteristic. The standard errors for the DD estimates are robust to heteroscedasticity and allow the error term to be correlated both within and across products with a lag of up to 12 months (Driscoll and Kraay 1998). The average price paid per dozen eggs in the three California markets grew by 54 cents more (a $20 \%$ increase) than it would have in the absence of the AW laws, assuming that the DD identifying assumptions hold. 
As shown in the rightmost column of the second row of table 2 , there was no discernible impact on quantity sold. Caution is warranted in giving a causal interpretation to our estimated impact for quantity, however. Unlike price, we do not have a strong theorybased argument for a common trend in quantity across markets, and ADF tests show that quantity was not cointegrated in California and our control markets prior to realized effects of the AW laws. ${ }^{12}$

The DD estimates for impacts on the proportion of eggs sold with different characteristics are as expected. Since conventional eggs would have been forced to change their housing systems in order to comply with the AW laws, we would expect prices of conventional eggs to rise, decreasing quantity demanded while raising quantity demanded for substitutes such as free-range and cage-free eggs. The percent impacts on the proportion of eggs sold that were organic, cage free, or free range are large, at $25 \%$ for organic and $33 \%$ for cage free and free range. Since the market shares of these products are low, nonconventionally produced eggs continue to make up a small portion of the retail egg market in the three California markets.

\section{Impacts of the AW laws on retail shell egg prices in California}

In order to estimate price effects more formally than what is presented in table 2 , we begin by estimating the following regression, weighting by units sold each month:

\footnotetext{
12 The ADF results are shown in the supplementary appendix, as are estimated quantity impacts for each California market. DD quantity estimates for Los Angeles are positive while estimates for San Diego and San Francisco are negative. Our trade and production data show a reduction in total availability, suggesting that the California markets not included in our scanner data also experienced decreases in quantity sold.
} 


$$
\text { price }_{i t}=\lambda_{t}+\beta_{1} C A_{i}+\beta_{2} P H X_{i}+\beta_{3} S L C_{i}+\beta_{4} C H I_{i}+\varphi x_{i}+e_{i t}
$$

where price $_{i t}$ is the unit value for product $i$ in month $t ; C A_{i}, P H X_{i}, S L C_{i}$, and $C H I_{i}$ are dummy variables equal to 1 for products observed in California and the respective control markets, $x_{i}$ is a vector of product characteristics, ${ }^{13}$ and $e_{i t}$ is the error term. The model includes fixed effects $\left(\lambda_{t}\right)$ for each of the 61 months observed in the data set. The time effects should control for changes in input prices and trade costs affecting local egg production since egg-production inputs (feed, labor, fuel, etc.) and components of trade costs (fuel, the interest rate) move across state borders. Time effects also control for changes in demand shifters that are common across markets.

In order to determine when the AW laws first affected shell egg prices in California as well as variation in the impact over time, we conduct a search for multiple unknown structural breaks in $\beta_{1}$ using the panel structural break test of Bai (2010). The procedure works in much the same way as the time-series structural break test of Bai and Perron (1998) used for our analysis of production impacts. We choose the initial break to minimize the sum of squared residuals from our estimate of equation (2) after adding an interaction between a break dummy and $C A_{i}$ to the model. ${ }^{14}$ If we retain the first break, we split the sample, estimate an additional break in each subsample, retain the break that yields the

\footnotetext{
${ }^{13}$ These include dummy variables for private label brands, packages sizes of a dozen eggs or less, color, cage free, free range, hormone free, and organic. We included all interaction terms except the interaction between package size and free range, which was dropped because of collinearity.

14 The parameter on the break dummy by itself is not identified because of the time effects, so we do not include it in the structural break test.
} 
biggest reduction in the sum of squared residuals, and decide whether to incorporate the second break into the model. This process continues until no additional breaks are retained. The key differences between the panel and time series procedures are that we do not have to trim the sample before estimating the breaks when using panel data, and that the number of breaks is chosen by minimizing BIC rather than by hypothesis testing. ${ }^{15}$

We estimate and retain four structural breaks in equation (2). The first break is in November 2014 and three subsequent breaks occur in February 2015, December 2015, and March 2016. Each structural break is shown in figure 4, along with the average price paid per dozen eggs in California as well as the pooled control markets. A sharp increase in the vertical distance between the two observed price series relative to their pre-break distance is visible right after the first break. The vertical distance narrows with each subsequent break, but appears to remain higher than what we observe pre-break.

\section{[FIGURE 4 ABOUT HERE]}

Based on the results of our structural breaks test, we estimate the following simple DD model:

$$
\text { price }_{i t}=\alpha+\beta_{1} C A_{i}+\sum_{b=1}^{4} \rho_{b} \text { Break }_{t}^{b}+\sum_{b=1}^{4} \delta_{b}\left(C A_{i} \times \text { Break }_{t}^{b}\right)+e_{i t}
$$

\footnotetext{
${ }^{15}$ In the Bai (2010) panel structural break method, inference on each break is done by constructing a confidence interval around the estimated date. However, the confidence interval will collapse around the estimated break date as the number of panels grows to infinity. In our case, the number of panels is so large that we obtain the narrowest possible confidence interval (+/- one month) for each estimated break. Bai suggests using model selection criteria such as AIC or BIC to choose the number of breaks when the crosssectional dimension of the data set is large.
} 
where $i$ indexes product and $t$ indexes month. Break $k_{t}^{b}$ is a dummy variable equal to 1 if month $t$ occurs after break $b$ but prior to break $b+1$. The impact of the AW laws on the average price paid per dozen eggs in California during the period covered by a given break is equal to $\delta_{b}$. In addition to the simple model in equation (3), we estimate models with product characteristics, fixed effects for each control market, and a full set of time effects, as in equation (2). We start with the simple model above because it requires no functional form assumptions to justify the use of OLS despite the fact that price $_{i t}$ is non-negative. ${ }^{16}$ Estimated impacts from equation (3) are equal to differences in quantity-weighted sample averages calculated by comparing California prices to the prices in the pooled control markets. Results are presented in table 3 .

\section{[TABLE 3 ABOUT HERE]}

As shown in table 3, the price impact of the AW laws was initially quite large but fell over time, settling in at an impact of between $9 \%$ and $11 \%$ over the last seven months of the observed time horizon. The evolution of price impacts is made clearer in figure 5, where we graph the observed average price per dozen in California and the counterfactual "no AW laws" average price. The latter price series was calculated by subtracting estimated price impacts from the observed average California price. The large vertical distance between the two series shortly after implementation of the AW laws illustrates that initial

\footnotetext{
${ }^{16}$ Estimating our price regression with $\log$ unit values resulted in percent impacts nearly identical to those of our results presented here. The log price results are in the supplementary appendix.
} 
price impacts were substantial. Towards the end of the two series, we see a narrowing of the vertical distance, which then remains steady for the remainder of the observed time horizon.

\section{[FIGURE 5 ABOUT HERE]}

\section{Consumer welfare impacts}

It is theoretically possible that the perception of improved treatment of hens in California increased demand for eggs in the state, causing a portion of resulting price increases. Whether this is the case has important implications for the estimation of consumer welfare impacts. However, there is no solid evidence suggesting that demand increases caused by the AW laws were anything other than negligible, a conclusion we reached based on several lines of evidence.

First, Google Trends data on internet searches for terms like "battery cage," "Proposition 2," "egg," and "hen" indicate no change in consumer interest in the welfare of egg-laying hens in California relative to control markets. While the first two of these four search terms were virtually non-existent in California and control markets, all results for the latter two indicated that variation in search popularity tracked the normal seasonal variation associated with Easter, Thanksgiving, and Christmas. Second, we conducted searches of the major newspapers in each Nielsen market for the term "battery cage". There were eight stories in 2014 and 2015 that had anything to do with hen housing, and half of these came from our California markets. While there was some media coverage of the issue, 
the results of our search are hardly indicative of the kind of sustained coverage that could shift demand. All of these results are developed in detail in the supplementary appendix. ${ }^{17}$

Next, we considered the experimental evidence on willingness-to-pay (WTP) for perceived improvement of housing standards for egg-laying hens. In the meta-analysis of Lagerkvist and Hess (2011), the price premium that consumers are willing to pay under a scenario roughly approximating that of the AW laws (improved hen treatment is mandated by law, compliant products are labeled, and consumers cannot choose to buy noncompliant products) ranges from $-38 \%$ to $49.2 \%$, depending on model specification. A more recent meta-analysis is that of Clark et al. (2016), who obtain an estimate of mean WTP for improved hen welfare of 0.09 Euros (10 cents) per dozen eggs from the studies surviving their review process. When adding additional control variables to their regression models, Clark et al. (2016) are unable to reject the null of zero WTP for improved hen welfare in three of five model specifications, and mean WTP is negative in three of five model specifications as well. Clark et al. (2016) conclude that the quality of the evidence for consumer willingness to pay for animal welfare is poor overall. Our reading of the experimental literature is that there is no basis for drawing a firm conclusion with respect to consumer WTP for improved treatment of hens.

Lastly, one could argue that the passage of the AW laws provides a revealedpreference argument in favor of consumer welfare gains from improved treatment of hens.

\footnotetext{
${ }^{17}$ We also considered estimation of a structural demand model, but for reasons explained in detail in the supplementary appendix, we do not believe this is a valid strategy in this instance.
} 
The passage of the laws was surprising given the low market share of cage-free eggs prior to the policy change. The AW laws appear to be a manifestation of the "consumer/citizen paradox," where voting behavior as well as stated preferences can contradict purchasing behavior (Aerts 2013). The explanation for the discrepancy in consumer and voter behavior in California could be much more simple, however, and consistent with our arguments for minimal consumer welfare gains stemming from the AW laws. The text of Proposition 2 stated that as a result of passing the law, farm animals would have sufficient room for "lying down, standing up, and fully extending (their) limbs; and turning around freely." This statement may have appeared quite reasonable to California voters, and there is nothing in it to suggest that large price increases might also result from passage of the AW laws (Norwood 2011).

In light of the above, we move forward with our consumer welfare analysis under the assumption that welfare gains stemming from perceived improvements in the treatment of hens were negligible. We check the robustness of our results to this and other assumptions. Our measure of consumer welfare is a first-order approximation to the equivalent variation (EV) taken from Deaton and Muellbauer (1980). ${ }^{18}$ This consumer welfare measure has the benefit of being consistent with theory without requiring the (potentially onerous) identifying assumptions of a full structural model of behavior. The $\mathrm{EV}$ is equal to the size of the lump sum transfer away from consumers in our three

\footnotetext{
${ }^{18}$ We derive our measure of consumer welfare in the supplementary appendix.
} 
California markets that would have left them just as well off in the absence of the AW laws as they are with the AW laws in place:

$$
\sum_{t=\tau}^{T} q_{t}^{1}\left(p_{t}^{1}-p_{t}^{0}\right)
$$

where $q_{t}^{1}$ is a row vector of quantities of different products purchased at time $t$ and $\left(p_{t}^{1}-p_{t}^{0}\right)$ is a column vector of price impacts of the AW laws. The superscripts on price and quantity denote potential outcomes, with a value of 1 indicating the observed value of the vector given the impacts of the AW laws and 0 indicating the unobserved counterfactual "no AW laws" value. Impacts begin in period $\tau$ and last through period $T$. The formula in equation (4) will understate the consumer welfare effects of the retail price increases caused by the AW laws, although the degree of approximation error should be small given that egg demand is highly inelastic. ${ }^{19}$ In addition, it should be understood that our consumer welfare measure covers the consumers included in the Nielsen market areas, and only measures the welfare effects of higher retail prices for eggs.

Estimation of (4) is complicated by the fact that we cannot simply plug in our earlier DD estimates of average price impacts, as this may result in bias. More specifically, if we

${ }^{19}$ To see why the error will be small, consider the case of a single product and time period. In this scenario, the graphical representation of equation (4) is given by the area of the rectangle with height equal to the price impact, $\left(p^{1}-p^{0}\right)$, and length equal to the quantity purchased at the observed price, $q^{1}$. This rectangle underestimates the EV by an area equal to the triangular shape bounded by the Hicksian demand curve, the counterfactual price $\left(p^{0}\right)$, and the quantity purchased at the observed price $\left(q^{1}\right)$. The size of the approximation error falls as demand becomes less elastic. Previous literature indicates that the demand curve for eggs is highly inelastic (Okrent and Alston 2011). 
let $\varepsilon_{t}$ be the vector of errors generated by subtracting our estimated price impacts for each California product at time $t$ from the true price impacts, then the overall error in our estimate of equation (4) will be given by:

$$
E V-\hat{E V}=\sum_{t=\tau}^{T} q_{t}^{1} \varepsilon_{t}
$$

Assuming that our estimated price impacts are correct on average so that the expected value of the $\varepsilon_{t}$ terms is zero, our measure of the EV will only be unbiased if observed quantities sold are uncorrelated with $\varepsilon_{t}$. It cannot be the case, for example, that price impacts on more popular products tend to be underestimated while impacts on less popular products tend to be overestimated.

To limit the bias in our estimated EV we need a richer model of price impacts. To that end, we estimate the following regression model:

$$
\begin{aligned}
& \text { price }_{i t}= \\
& \lambda_{t}+\sum_{m=1}^{6} \beta_{m} D_{i m}+\sum_{m=1}^{6} \phi_{m}\left(D_{i m} \times z_{i}\right)+\sum_{b=1}^{4} \theta_{b}\left(\text { Break }_{t}^{b} \times z_{i}\right)+ \\
& \sum_{m=1}^{3} \sum_{b=1}^{4} \delta_{m b}\left(D_{i m} \times \text { Break }_{t}^{b}\right)+\sum_{m=1}^{3} \sum_{b=1}^{4} \omega_{m b}\left(D_{i m} \times z_{i} \times \text { Break }_{t}^{b}\right)+e_{i t}
\end{aligned}
$$

where $z_{i}$ is a vector of product characteristics, including dummies for whether a product was produced conventionally, egg color, and all interactions thereof. The $m$ subscript denotes market, with California markets numbered one through three and control markets numbered four through six. The dummy variable $D_{i m}$ equals 1 if product $i$ is sold in market $m$. From left to right, the five terms in the second row of equation (6) include a full set of 
time effects, fixed effects for the six markets in the data set, interactions between the market dummy variables and product characteristics, and interactions between the structural break dummy variables and product characteristics. The three terms in the third row represent interactions between the California market dummy variables and the structural break dummies; interactions between the California markets, product characteristics, and break dummies; and the error term. Equation (6) is estimated by OLS, i.e. we do not weight by quantity. For each product, the estimated impact on its price per dozen in a given month is given by a combination of elements from the $\delta_{m b}$ and $\omega_{m b}$ parameter vectors. The EV is estimated by substituting estimated price impacts from equation (6) as well as observed quantities sold into equation (4).

Despite estimating a richer model of price impacts, there may still be unexplained variation in price impacts that is correlated with quantity sold each month. An easy solution to this problem would be to condition price impacts on $q^{1}$. However, this is not an option because we observe $q^{0}$ rather than $q^{1}$ in control markets. To check sensitivity of the estimated EV to correlation between price impacts and quantity sold, we create a new variable equal to the average number of dozens sold for each product by month (January through December) in the months prior to any AW law price impacts. If past seasonal variation in quantity sold is a good predictor of current quantity sold, then defining price impacts as a function of this new variable will serve as a stringent robustness check on our EV estimates. A regression of units sold on our newly created variable using data observed 
after the initial structural break returns an R-squared of 0.26 , indicating that the correlation between past and future quantity sold by month is indeed fairly high.

Denoting our seasonal average quantity variable as $\bar{q}_{i}$, we estimate the following regression model as a robustness check:

$$
\begin{aligned}
& \text { price }_{i t}= \\
& \lambda_{t}+\sum_{m=1}^{6} \beta_{m} D_{i m}+\sum_{b=1}^{4} \rho_{b} \text { Break }_{t}^{b}+\sum_{m=1}^{6} \phi_{m}\left(D_{i m} \times z_{i}\right)+\sum_{b=1}^{4} \theta_{b}\left(\text { Break }_{t}^{b} \times z_{i}\right)+ \\
& \sum_{m=1}^{3} \sum_{b=1}^{4} \delta_{m b}\left(D_{i m} \times \text { Break }_{t}^{b}\right)+\sum_{m=1}^{3} \sum_{b=1}^{4} \omega_{m b}\left(D_{i m} \times z_{i} \times \text { Break }_{t}^{b}\right)+ \\
& \sum_{b=1}^{4} \gamma_{b}\left(\text { Break }_{t}^{b} \times \bar{q}_{i}\right)+\sum_{b=1}^{4} \eta_{b}\left(\text { Break }_{t}^{b} \times z_{i} \times \bar{q}_{i}\right)+\sum_{m=1}^{3} \sum_{b=1}^{4} \psi_{m b}\left(D_{i m} \times \text { Break }_{t}^{b} \times \bar{q}_{i}\right)+ \\
& \sum_{m=1}^{3} \sum_{b=1}^{4} \xi_{m b}\left(D_{i m} \times z_{i} \times \text { Break }_{t}^{b} \times \bar{q}_{i}\right)+e_{i t}
\end{aligned}
$$

Rows two and three of equation (7) are identical to those of equation (6). New terms are included in rows four and five of equation (7). In addition to $\delta_{m b}$ and $\omega_{m b}$, price impacts now include additional parameter vectors $\psi_{m b}$ and $\xi_{m b}$.

Estimation of price impacts is further complicated by the fact that we only observe prices for products when they have positive quantities sold. Because we are estimating price impacts on individual products rather than the impact on the average price paid per dozen, missing price information could bias our estimated EV. As an additional robustness check, we estimate the approximate EV after imputing missing prices. To impute missing prices, we first assign observations to cells by market, month, color, and production system (conventional or other). Within each cell, we compute the maximum price among products with positive quantities sold, and impute missing prices within each cell using the cell 
maximums. We then re-estimate equation (6) as well as the approximate EV using observed as well as imputed prices. ${ }^{20}$ Results are presented in table 4.

Finally, as a robustness check on the possibility that consumers may have benefited from perceived improvements in the treatment of hens, we also estimate equation (7) after subtracting eight cents from the price of conventional eggs sold in California once the AW laws had begun to affect prices. The figure of eight cents is drawn from Norwood and Lusk (2011). Using a non-hypothetical experiment, Norwood and Lusk (2011) estimate that consumers are willing to pay an average of eight cents per dozen in order to move hens from 69 square inches to 155 square inches of space, holding all other housing characteristics constant (including the use of cages). Given that 155 square inches is $34 \%$ greater than the minimum standard imposed by the AW laws, incorporating the price premium estimated by Norwood and Lusk (2011) into our analysis ought to serve as a strong robustness check on our results.

\section{[TABLE 4 ABOUT HERE]}

The top row of table 4 gives the estimate of the total approximate EV across the three California markets for all 22 months observed after the AW laws began to affect retail egg prices. Subsequent rows give the welfare impacts per month for the time intervals defined by each estimated structural break. Results in column (1) are based on our estimate of equation (6) while column (2) is based on equation (7). Column (3) presents results

\footnotetext{
${ }^{20} \mathrm{We}$ also imputed prices using cell means, but the results were nearly identical to what we obtain without imputation, and are not presented here.
} 
obtained after imputing prices using the scheme described above and re-estimating equation (6). Column (4) gives the results obtained after incorporating the animal welfare adjustment described above.

The estimated cumulative welfare losses from higher retail prices are large, although they appear more modest when considered on a per household basis. Dividing our estimated total welfare losses by the number of households in the three California markets yields a per household welfare loss of between 55 and 68 cents per month over 22 months, or between about $\$ 6.63$ and $\$ 8.17$ per year. Obviously, the incidence of welfare impacts will depend on individual shopping habits.

Monthly welfare losses were initially quite high but fell by 2016. Converting the monthly welfare losses shown in table 4 to household losses per month yields monthly losses of 60 to 83 cents per household from December 2014 through February 2015, 61 to 77 cents from March through December 2015, 16 to 23 cents from January through March 2016, and 17 to 67 cents from April through July 2016. The upper bound on the April-July effect is a result of the large price impacts obtained when imputing missing prices. If the April-July 2016 welfare impacts are representative of effects on consumer welfare going forward, annual welfare losses from higher retail prices will be at least $\$ 2$ per household in future years in our three California markets.

\section{Conclusion}

As touched upon in the introduction, economists and animal welfare advocates have made widely varying predictions about the potential effects of the AW laws and similar 
legislation. On the production side, our results clarify this debate by demonstrating that the impact of regulations for improved farm animal housing can be drastic. A limitation of our results is that the producer welfare effects of the regulations remain unclear. By creating a barrier to trade and reducing in-state supply, the AW laws may have helped California egg producers enjoy rents that they would not have otherwise obtained. On the other hand, the large decrease in egg production and the number of hens may be indicative of an exodus of California producers from the egg industry in the face of potential losses.

If the results from our consumer analysis for the last seven months observed in our data set are representative of the impacts of the AW laws going forward, then California consumers will experience annual welfare losses of at least $\$ 25$ million in future years from higher retail egg prices alone. This is far smaller than the estimated annual consumer surplus loss of between $\$ 408$ and $\$ 853$ million reported by Malone and Lusk (2016), the only other ex-post analysis of the AW laws to date. In addition to differences in econometric methodology and the fact that we can account for product differentiation, this discrepancy in welfare measures is caused by three factors. First, our welfare measure is an estimate of the EV, making it inherently more conservative than the consumer surplus calculation of Malone and Lusk (2016). Second, Malone and Lusk (2016) use quantities based on USDA disappearance data rather than focusing solely on the retail sector, making our estimate still more conservative relative to theirs. Lastly, Malone and Lusk (2016) use an estimated price impact of about 56 cents per dozen in computing the consumer surplus loss, whereas the impact of the AW laws on the average price per dozen eggs in the last seven months covered by our data is 19 cents. Plugging an estimated price impact of 19 
cents into the consumer welfare formula of Malone and Lusk (2016) yields a projected annual welfare loss of between $\$ 137$ and \$289 million for California consumers. This figure suggest that while our estimated annual consumer welfare losses of \$25 million from higher retail prices are substantial, they represent just a portion of the cost of happier hens to California consumers. 


\section{References}

Aerts, S. 2013. "The Consumer Does Not Exist: Overcoming the Citizen/Consumer Paradox by Shifting Focus." In The Ethics of Consumption: The Citizen, the Market and the Law, edited by H. Röcklinsburg and P. Sandin, 172-176. Wageningen: Wageningen Academic Publishers.

Allender, W., and T. Richards. 2010. "Consumer Impact of Animal Welfare Regulation in the California Poultry Industry." Journal of Agricultural and Resource Economics 35 (3): 424-442.

Andrews, D. 1993. "Testing for Parameter Instability and Structural Change with Unknown Change Point." Econometrica 61 (4): 821-856.

Angrist, J., and J. Pischke. 2009. Mostly Harmless Econometrics: An Empiricist's Companion. Princeton, New Jersey: Princeton Press.

Bai, J. 2010. "Common Breaks in Means and Variance for Panel Data." Journal of Econometrics 157 (1): 78-92.

Bai, J., and P. Perron. 1998. "Estimating and Testing Linear Models with Multiple Structural Changes." Econometrica 66 (1): 47-78.

Bell, D. 2013. California's Egg Requirements - 2015. Egg Economics Update, Iowa State University, Ames, Iowa: Egg Industry Center.

California Department of Food and Agriculture. 2013. "Egg Safety Rule Questions and Answers." 
Clark, B., G. Stewart, L. Panzone, I. Kyriazakis, and L. Frewer. 2016. "Citizens, Consumers and Farm Animal Welfare: A Meta-Analysis of Willingness-to-Pay Studies." Food Policy 68 (1): 112-127.

Deaton, A., and J. Muellbauer. 1980. Economics and Consumer Behavior. New York: Cambridge University Press.

Driscoll, J., and A. Kraay. 1998. "Consistent Covariance Matrix Estimation with Spatially Dependent Panel Data." The Review of Economics and Statistics 80 (4): 549-560.

Engle, R., and C. Granger. 1987. "Co-Integration and Error Correction: Representation, Esitmation, and Testing." Econometrica 55 (2): 251-276.

Hall, C. 2008. "Prop. 2 Pits Animal Rights Against Farmers'." Los Angeles Times, October 21. http://articles.latimes.com/2008/oct/21/local/me-animals21.

Howitt, R., D. MacEwan, J. Medellín-Azuara, J. Lund, and D. Sumner. 2015. Economic Analysis of the 2015 Drought for California Agriculture. University of California, Davis, UC Davis Center for Watershed Services.

Ivancic, L., W. Diewert, and K. Fox. 2011. "Scanner Data, Time Aggregation, and the Construction of Price Indices." Journal of Econometrics 161 (1): 24-35.

Lagerkvist, C., and S. Hess. 2011. "A Meta-Analysis of Consumer Willingness to Pay for Farm Animal Welfare." European Review of Agricultural Economics 38 (1): 5578. 
Malone, T., and J. Lusk. 2016. "Putting the Chicken Before the Egg Price: An Ex Post Analysis of California's Battery Cage Ban." Journal of Agricultural and Resource Economics 41 (3): 518-532.

Nassauer, S. 2015. "Wal-Mart Encourages Meat and Egg Suppliers to Curb Antibiotic Use." The Wall Street Journal, May 22. http://www.wsj.com/articles/wal-martencourages-meat-suppliers-to-curb-antibiotic-use-1432305974.

Norwood, F. 2011. "The Private Provision of Animal-Friendly Eggs and Pork." American Journal of Agricultural Economics 94 (2): 509-514.

Norwood, F., and J. Lusk. 2011. "A Calibrated Auction-Conjoint Valuation Method: Valuing Pork and Eggs Produced under Differing Animal Welfare Conditions." Journal of Environmental Economics and Management 62 (1): 80-94.

Okrent, A., and J. Alston. 2011. Demand for Food in the United States: A Review of the Literature, Evaluation of Previous Estimates, and Presentation of New Estimates of Demand. Monograph, Giannini Foundation.

Otto, D., M. Ibarburu, and L. Schulz. 2013. Economic Importance of the Iowa Egg Industry. Ames: Iowa State University.

Pacelle, W. 2016. A Humane Nation. December 21. Accessed December 29, 2016. http://blog.humanesociety.org/wayne/2016/12/sodexo-panera-bread-announcemajor-reforms-broiler-chicken-welfare.html. 
Polansek, T., and R. Nickel. 2015. "McDonald's Cage-Free Egg Pledge Pressures Farmers, $\begin{array}{llll}\text { Squeezes } & \text { Supply." } & \text { Rueters, } & \text { September }\end{array}$ http://www.reuters.com/article/2015/09/22/us-usa-mcdonalds-eggsidUSKCNORM27T20150922.

Sumner, D., H. Gow, D. Hayes, W. Matthews, B. Norwood, J. Rosen-Molina, and W. Thurman. 2011. "Economic and Market Issues on the Sustainability of Egg Production in the United States: Analysis of Alternative Production Systems." Poultry Science 90 (1): 241-250.

Sumner, D., J. Rosen-Molina, W. Matthews, J. Mench, and K. Richter. 2008. Economic Effects of Proposed Restrictions on Egg-Laying Hen Housing in California. Davis, CA: University of California Agricultural Issues Center.

USDA Economic Research Service (ERS). 2015. Food Availability (Per Capita) Data System. Accessed October 13, 2015. http://www.ers.usda.gov/data-products/foodavailability-(per-capita)-data-system.aspx.

Ward, J. 2014. From Battery Cages to Barns: A Cost-Benefit Analysis of a National Standard for Cage-Free Egg Production. School of Public Policy Capstones, School of Public Policy, Amherst, MA: University of Massachusetts-Amherst.

White, H. 2006. "Time-Series Estimation of the Effects of Natural Experiments." The Journal of Econometrics 135 (1): 527-566. 


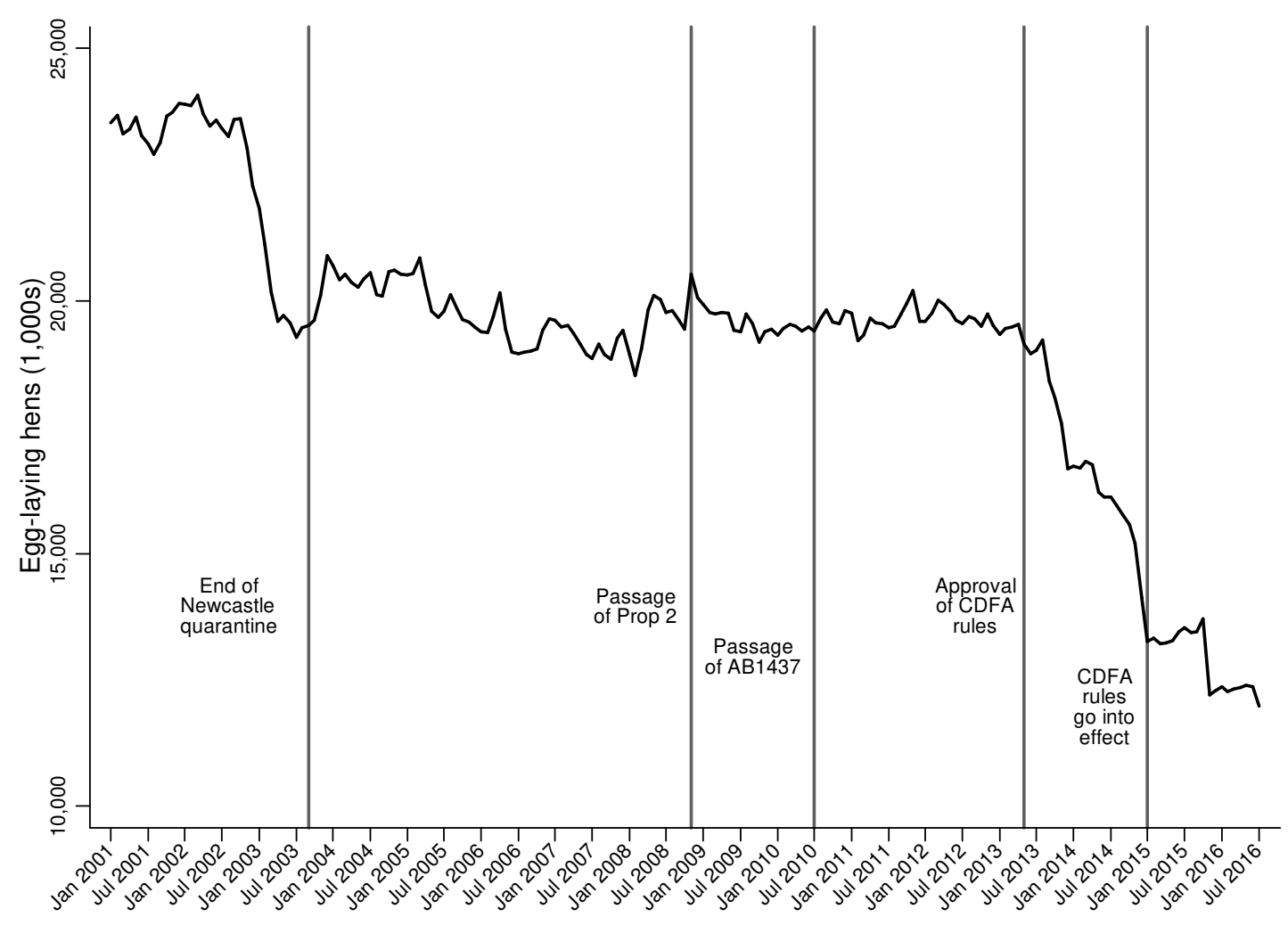

Figure 1. Egg-laying hens in California and timeline of events 


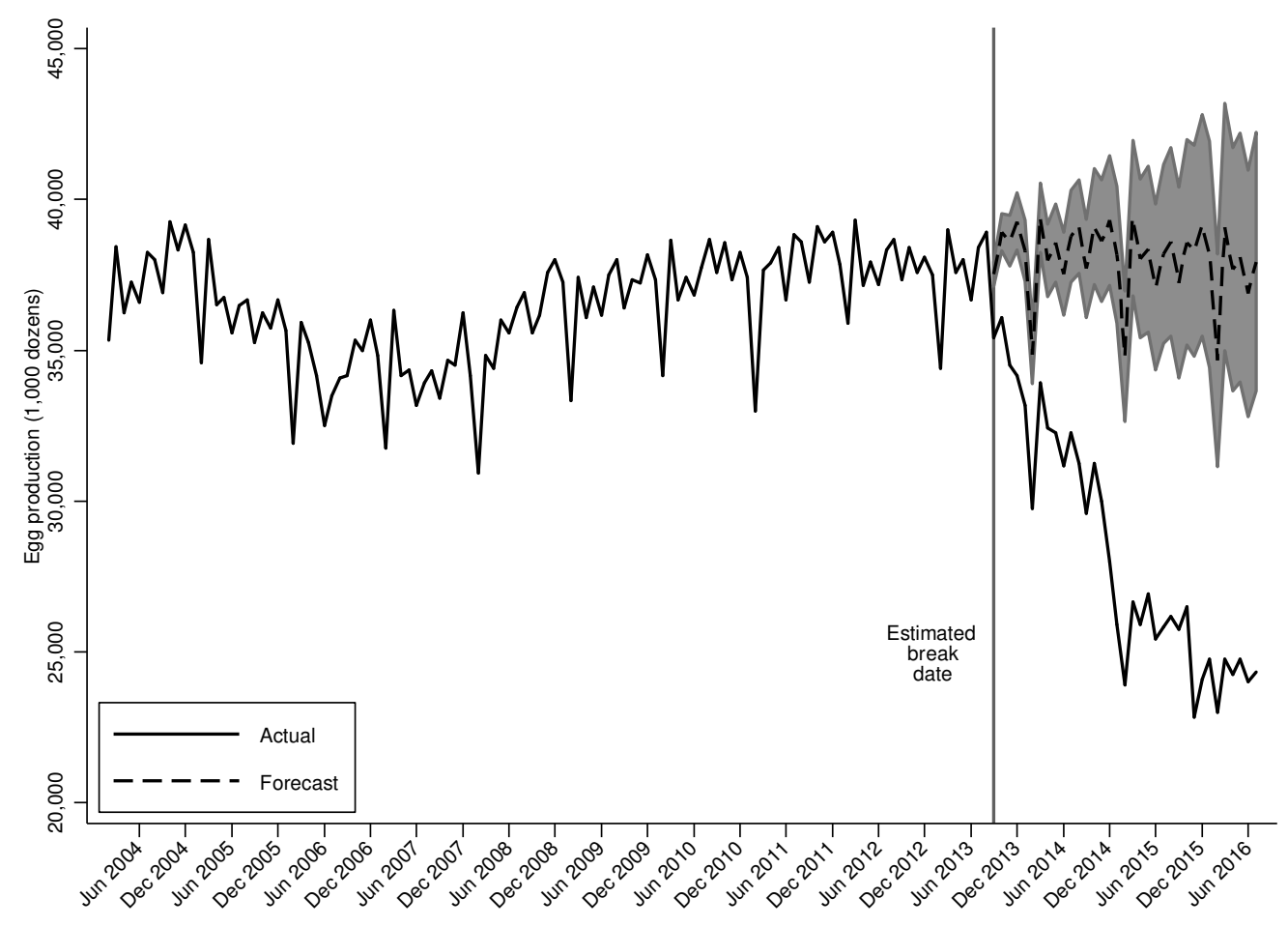

Figure 2. Actual and forecasted quantity of eggs produced in California 


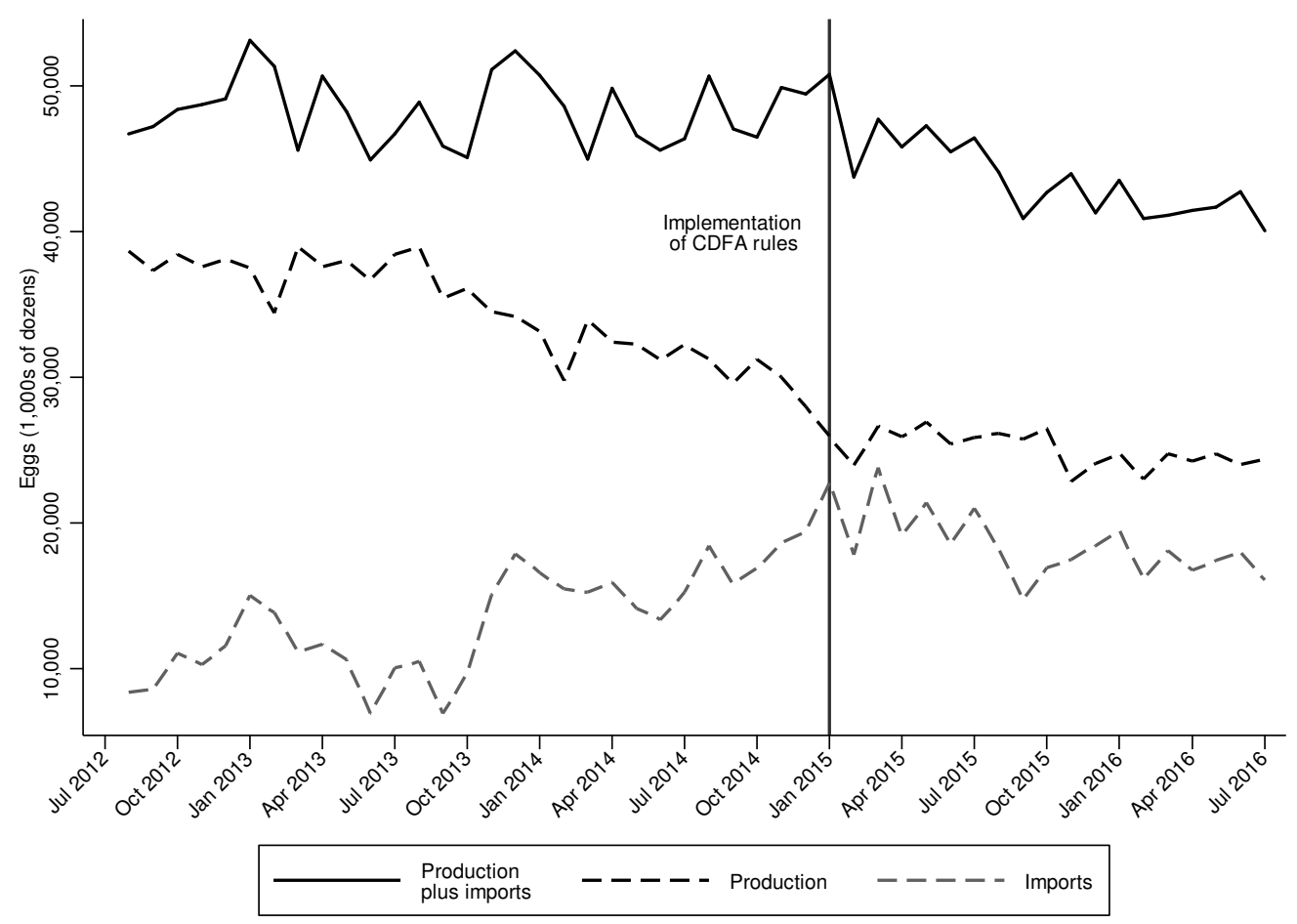

Figure 3. Production and imports of shell eggs in California 


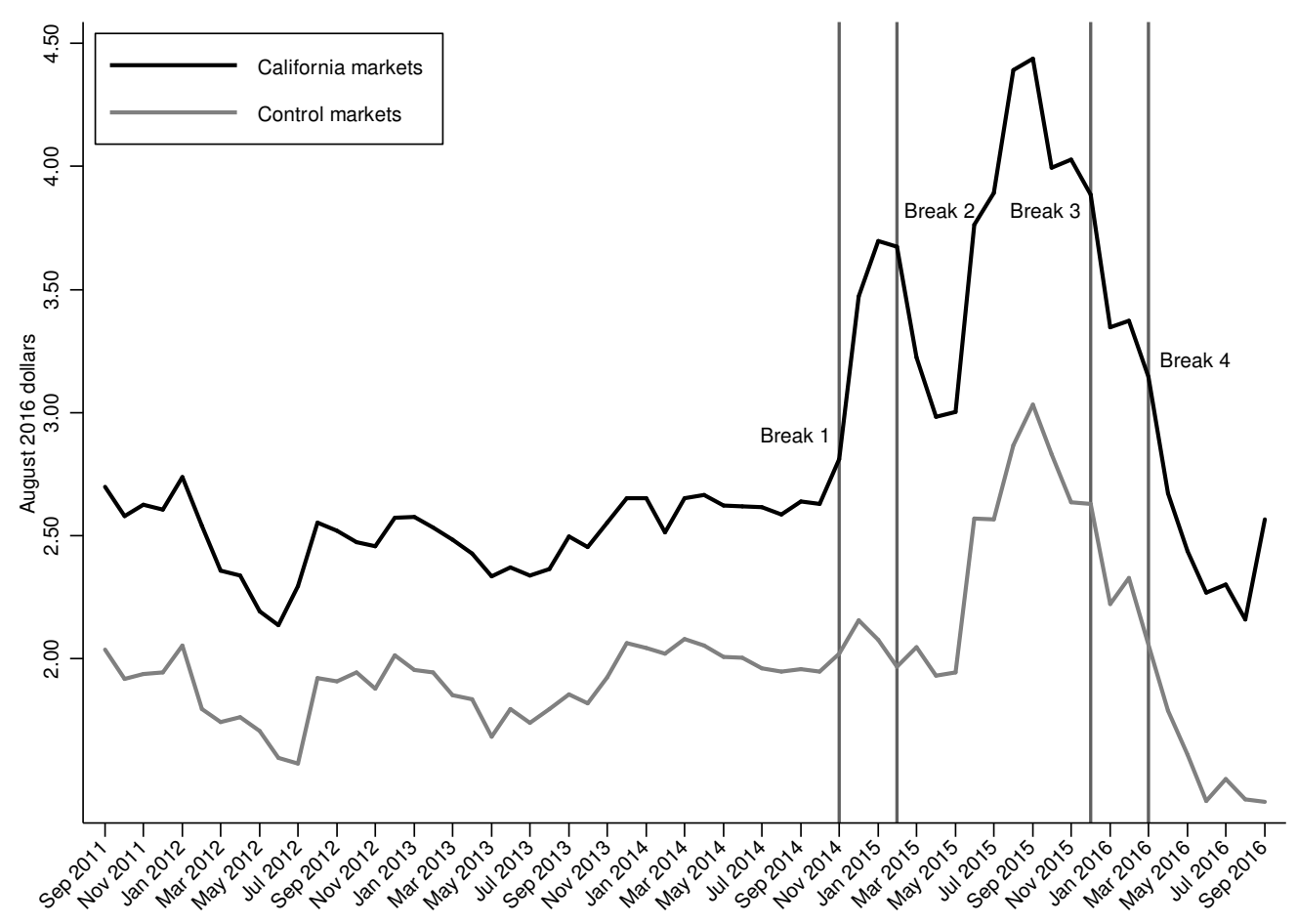

Figure 4. Average price paid per dozen eggs 


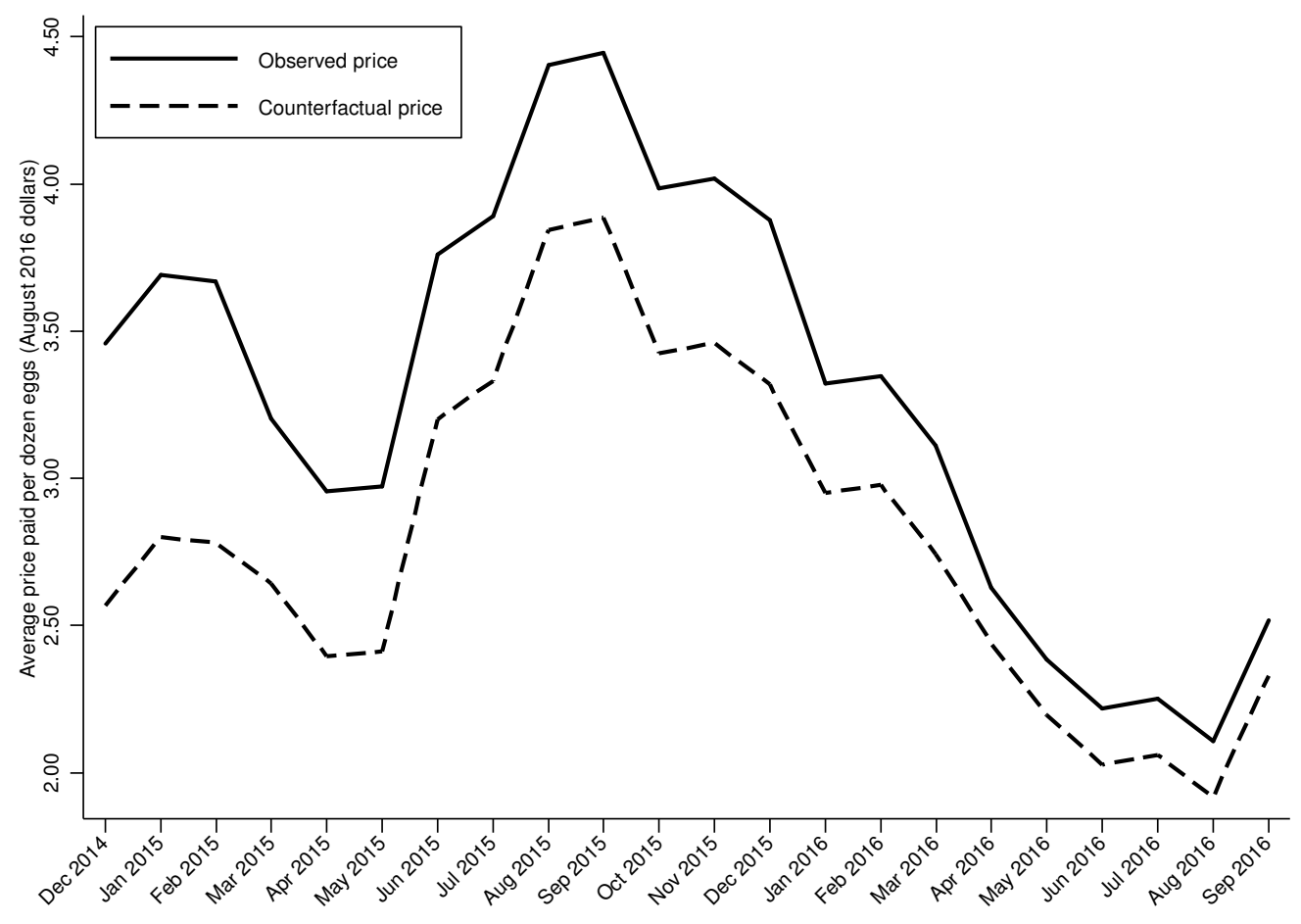

Figure 5. Observed and counterfactual average price paid per dozen eggs in three California markets 


\section{Table 1. Monthly impacts of the AW laws on California egg production}

\begin{tabular}{|c|c|c|c|}
\hline & Egg-laying hens $(1,000 \mathrm{~s})$ & Egg production (1,000 dozens) & Eggs per 100 egg-laying hens \\
\hline & $\begin{array}{l}\text { AW law } \\
\text { impact }\end{array}$ & $\begin{array}{l}\text { AW law } \\
\text { impact }\end{array}$ & $\begin{array}{c}\text { AW law } \\
\text { impact }\end{array}$ \\
\hline Mean forecast error & $-4,468.72 * * *$ & $-9,972 * * *$ & -77.83 \\
\hline Standard error & [331.70] & {$[1,156.31]$} & [42.02] \\
\hline $95 \%$ Confidence interval & $\{-5,034.09 ;-3,739.73\}$ & $\{-12,030.13 ;-7,461.12\}$ & $\{-161.65 ; 2.28\}$ \\
\hline Pre-forecast mean & 19,541 & 37,646 & 2,312 \\
\hline
\end{tabular}


Table 2. Scanner data summary statistics

\begin{tabular}{lccccc}
\hline & \multicolumn{2}{c}{ California } & \multicolumn{2}{c}{ Pooled control markets } & Pifference-in- \\
& Post-break & Pre-break & Post-break & Pre-break & $\begin{array}{c}\text { differences } \\
\text { Average price paid per dozen eggs }\end{array}$ \\
& 3.24 & 2.47 & 2.09 & 1.85 & $0.54^{* * *}$ \\
Quantity sold per month (1,000s of & $(1.40)$ & $(0.99)$ & $(0.98)$ & $(0.72)$ & {$[0.112]$} \\
dozens) & 11.96 & 11.40 & 10.62 & 10.41 & 0.34 \\
Average product characteristics & $(59.31)$ & $(48.95)$ & $(47.14)$ & $(45.82)$ & {$[0.284]$} \\
Conventional & & & & & $-0.04^{* * *}$ \\
& 0.84 & 0.90 & 0.93 & 0.95 & {$[0.006]$} \\
White egg & $(0.368)$ & $(0.304)$ & $(0.263)$ & $(0.223)$ & $-0.06 * * *$ \\
Cage free & 0.80 & 0.88 & 0.91 & 0.94 & {$[0.010]$} \\
& $(0.404)$ & $(0.329)$ & $(0.282)$ & $(0.244)$ & $0.03 * * *$ \\
Free range & 0.13 & 0.08 & 0.07 & 0.05 & {$[0.007]$} \\
& $(0.331)$ & $(0.268)$ & $(0.250)$ & $(0.208)$ & $0.01 * * *$ \\
Organic (USDA certified or & 0.04 & 0.02 & 0.00 & 0.00 & {$[0.003]$} \\
claimed on package) & $(0.188)$ & $(0.138)$ & $(0.065)$ & $(0.041)$ & $0.02^{* * * *}$ \\
\hline
\end{tabular}

Notes: All statistics calculated using monthly data. Standard deviations in parentheses. Driscoll-Kraay standard errors for the difference-in-differences estimator in brackets; $* \mathrm{p}<0.10, * * \mathrm{p}<0.05, * * * \mathrm{p}<0.01$. Average price paid is in August 2016 dollars. Other than "Quantity sold," all results were generated by weighting by units sold. All product characteristic variables are computed using weighted averages of dummy variables for the characteristic in question. 
Table 3. Impacts on average price paid per dozen eggs in three California markets

\begin{tabular}{|c|c|c|c|c|c|c|}
\hline & $\begin{array}{l}\text { Impact in } \\
\text { dollars }\end{array}$ & $\begin{array}{l}\text { Percent } \\
\text { impact }\end{array}$ & $\begin{array}{l}\text { Impact in } \\
\text { dollars }\end{array}$ & $\begin{array}{l}\text { Percent } \\
\text { impact }\end{array}$ & $\begin{array}{l}\text { Impact in } \\
\text { dollars }\end{array}$ & $\begin{array}{l}\text { Percent } \\
\text { impact }\end{array}$ \\
\hline $\begin{array}{l}\text { All months after first break } \\
\text { (Dec. } 2014 \text { - Sep. 2016) }\end{array}$ & $\begin{array}{l}0.56^{* * *} \\
{[0.026]}\end{array}$ & $21 \%$ & $\begin{array}{l}0.47 * * * \\
{[0.019]}\end{array}$ & $17 \%$ & $\begin{array}{l}0.47^{* * *} \\
{[0.019]}\end{array}$ & $17 \%$ \\
\hline Dec. 2014 - Feb. 2015 & $\begin{array}{l}0.97 * * * \\
{[0.039]}\end{array}$ & $37 \%$ & $\begin{array}{c}0.89 * * * \\
{[0.041]}\end{array}$ & $33 \%$ & $\begin{array}{c}0.89 * * * \\
{[0.041]}\end{array}$ & $33 \%$ \\
\hline Mar. 2015 - Dec. 2015 & $\begin{array}{l}0.65^{* * *} * \\
{[0.046]}\end{array}$ & $21 \%$ & $\begin{array}{c}0.54 * * * \\
{[0.027]}\end{array}$ & $17 \%$ & $\begin{array}{c}0.54 * * * \\
{[0.028]}\end{array}$ & $17 \%$ \\
\hline Jan. 2016 - Mar. 2016 & $\begin{array}{l}0.49 * * * \\
{[0.014]}\end{array}$ & $18 \%$ & $\begin{array}{c}0.38 * * * \\
{[0.016]}\end{array}$ & $13 \%$ & $\begin{array}{c}0.37 \text { *** } \\
{[0.016]}\end{array}$ & $13 \%$ \\
\hline Mar. 2016 - Sep. 2016 & $\begin{array}{c}0.23 * * * \\
{[0.017]}\end{array}$ & $11 \%$ & $\begin{array}{c}0.19^{* * *} \\
{[0.014]}\end{array}$ & $9 \%$ & $\begin{array}{c}0.19^{* * *} \\
{[0.014]}\end{array}$ & $9 \%$ \\
\hline Product characteristics & No & & Yes & & Yes & \\
\hline State fixed effects & No & & Yes & & Yes & \\
\hline Month fixed effects & No & & No & & Yes & \\
\hline R-squared & 0.628 & & 0.898 & & 0.911 & \\
\hline Observations & 51,263 & & 51,263 & & 51,263 & \\
\hline
\end{tabular}


Table 4. Consumer welfare effects of the AW laws in three California markets

\begin{tabular}{|c|c|c|c|c|}
\hline & (1) & (2) & (3) & (4) \\
\hline $\begin{array}{l}\text { Total welfare loss over observed time } \\
\text { period (Dec. } 2014 \text { - Sep. 2016) }\end{array}$ & $\begin{array}{c}120,470,035 * * * \\
{[6,634,744]}\end{array}$ & $\begin{array}{c}135,093,160 * * * \\
{[6,684,787]}\end{array}$ & $\begin{array}{c}144,091,180 * * * \\
{[20,439,588]}\end{array}$ & $\begin{array}{c}116,943,638 * * * \\
{[6,684,788]}\end{array}$ \\
\hline \multicolumn{5}{|l|}{ Monthly losses } \\
\hline Dec. 2014 - Feb. 2015 & $7,566,371 * * *$ & $8,024,628 * * *$ & $5,773,021^{* * *}$ & $7,225,562 * * *$ \\
\hline \multirow[t]{2}{*}{ Mar. 2015 - Dec. 2015} & $6,814,994 * * *$ & $7,376,788 * * *$ & $5,914,774 * * *$ & $6,602,865 * * *$ \\
\hline & {$[498,898]$} & {$[500,178]$} & {$[955,728]$} & {$[500,178]$} \\
\hline \multirow[t]{2}{*}{ Jan. 2016 - Mar. 2016} & $1,516,006^{* * * *}$ & $1,723,603 * * *$ & $2,216,099 * * *$ & $1,510,559 * * *$ \\
\hline & {$[39,214]$} & {$[41,681]$} & {$[253673]$} & {$[41,681]$} \\
\hline $\begin{array}{l}\text { Impacts vary by egg color and } \\
\text { production system }\end{array}$ & Yes & Yes & Yes & Yes \\
\hline Impacts vary by pre-break dozens sold & No & Yes & No & Yes \\
\hline Animal welfare adjustment & No & No & No & Yes \\
\hline Imputation of missing prices & No & No & Yes & No \\
\hline Observations & 51,263 & 51,263 & 117,245 & 51,263 \\
\hline
\end{tabular}

Notes: ${ }^{*} \mathrm{p}<0.10, * * \mathrm{p}<0.05, * * * \mathrm{p}<0.01$. All impacts are measured in August 2016 dollars. Standard errors are in brackets and were estimated using the delta method as applied to the Driscoll-Kraay estimate of the regression parameter covariance matrix. To impute prices in column (3), we divide products into cells by market, month sold, and characteristics (conventional and color). Products with zero quantity sold (and therefore no observed price) receive an imputed price equal to the maximum price among products with positive quantities sold in the same cell. "Animal welfare adjustment" subtracts eight cents off of the price per dozen for conventional eggs in California after December 2014; eight cents is the mean WTP per dozen eggs for an expansion of hen cages to 155 square inches of floor space reported in Norwood and Lusk (2011). 